\title{
FISH FAUNA OF THE ANAMALAI HILL RANGES, WESTERN GHATS, INDIA
}

\author{
K. Rema Devi, T.J. Indra, M.B. Raghunathan and M.S. Ravichandran
}

Zoological Survey of India, Southern Regional Station, \# 130, Santhome High Road, Chennai 600028, Tamil Nadu, India

\begin{abstract}
Based on the surveys undertaken by the Southern Regional Station, Zoological Survey of India and from earlier reports from Anamalai, Nelliampathi, Parambikulam WLS and Cardamom hills, a comprehensive list of the fish fauna of the Anamalai hill ranges is provided here. It comprises of 88 species including some new species described recently and several new records. A note on endemicity and species diversity is provided.
\end{abstract}

\section{KEYWORDS}

Anamalai hills, Cardamom hills, checklist, freshwater fish, Indira Gandhi Wildlife Sanctuary, Nelliampathi hills, Parambikulam Wildlife Sanctuary, review, Western Ghats

An account of the topography, drainages and taxonomic details of the fish fauna of each drainage in the Anamalai and Nelliampathi hills and their zoogeographical significance was reported by Silas (1951). Subsequently, Jayaram et al. (1976) studied the ichthyofauna of the Cardamom and Agastya hill ranges-two spurs of the Anamalai range. Biju et al. (1999) surveyed the Parambikulam Wildlife Sanctuary during 19961997 and reported the ichthyofaunal diversity. Recently, the Southern Regional Station carried out six extensive surveys of the Indira Ganghi Wildlife Sanctuary in Anamalais during 199698 and the fish specimens collected were identified as belonging to 58 species, which includes 29 new reports and one new species. An updated ichthyofaunal list comprising 88 species under 20 families and eight orders of the Anamalai hill ranges is presented here (Table 1) based on the station's collections and from earlier reports. The classification followed here is after Jayaram (1999) and Menon (1999).

\section{DISCUSSION}

Silas (1951) listed 25 species from Anamalai hills and 10 species from Nelliampathi hills (Table 1). His study extended the distribution of several species earlier known only in the central division of the Western Ghats to the southern division below the Palghat gap. Earlier work on the southern Western Ghats after Day $(1865,1875-78)$ is by Herre $(1942,1945)$ who described two new species, a sisorid catfish Glyptothorax housei and a homolopterid, Homaloptera montana and extended the distribution of Travancoria jonesi Hora. Silas (1951) in his faunal account discussed the extension of range of Salmostoma acinaces Val. (= Chela argentea Day), Barbodes carnaticus (= Barbus (Puntius) carnaticus), Osteochilus (Osteochilichthys) thomassi and Batasio travancoria and listed two endemic species described by Herre viz., Homaloptera montana and Glyptothorax housei. He further reported five species from the Cochin part of the Anamalai hills viz., Barilius bakeri, Puntius denisoni, Travancoria jonesi, Noemacheilus triangularis and Batasio travancoria. The species Glyptothorax prox madraspatanus (Day) reported by Silas from Anamalais has been subsequently described by him as a new species G. anamalaiensis. Jayaram et al. (1976) collected and reported 32 species from Cardamom hills with four new records to the area, viz. Barilius bakeri, Osteobrama bakeri, Hypselobarbus thomassi and Pristolepis marginatus. The listing of Lepidocephalus guntea (Val.) needs confirmation and hence not included in the present list.

Biju et al. (1999) surveyed the Parambikulam Wildlife Sanctuary, which lies in a valley between the Anamalai and Nelliampathi hill ranges in the Palakkad district of Kerala. They reported 41 species of which nine species are new additions to the upper reaches of Anamalai ranges and include two new species described from the Chalakudy river recently, viz., Osteochilichthys longidorsalis (Pethiyagoda \& Kottelat, 1996) and Garra surendranathanii (Shaji et al., 1996). Macrognathus guentheri listed by them has recently been placed under the synonymy of M. malabaricus (Menon, 1999). Nine new additions to the ichthyofauna are the following: Anguilla bengalensis Gray, Esomus danricus (Hamilton), Osteochilichthys longidorsalis Pethiyagoda and Kottelat, Garra surendranathanii Shaji et al., Glyptothorax lonah (Sykes), Clarias batrachus (Linn.), Etroplus suratensis (Bloch) and Channa marulius (Hamilton).

The present collection yielded 58 species from IGWLS Anamalai hills of which, 29 species are new additions (Table 1) to the IGWLS and 20 to the Anamalai hills, including one new species Heteropneustes longipectoralis (Rema Devi \& Raghunathan, 1999). Several species reported only from central Western Ghats have now been recorded from the southern ranges beyond the Palghat gap. The extension of range of Noemacheilus monilis has been discussed (Indra et al., 1998). Other collections of significance are Hypselobarbus dubius first described from Bhavani River at base of Nilgiris subsequently reported from Manimuthar river has now been collected from the Anamalai hills. Puntius bimaculatus (B. puckelli) earlier considered as a juvenile of $P$. dorsalis has been collected from these hills. Interestingly this species is found to be the most dominant Puntius species in the hill ranges of the Eastern Ghats especially Javadi hills. Puntius punctatus earlier considered as a synonym of Puntius tincto has been kept as a separate species (Menon, 1999) and both these species have been collected from IGWLS. Garra hughi described from the Cardamom and Palani hills has been collected from the upper Aliyar and Kilkallar rivers. A detailed study on the species with reference to its squamation had been carried out (Rema Devi \& Indra, 1999). Garra mcclellandi (Jerdon) also an endemic species of the Western Ghats has been collected from the two hill streams in Navamalai and Sirkarpathy. The homolopterid Bhavania australis, a rare species is a new addition to the Anamalai hills, earlier known from the hill streams of Nilgiris, Silem Valley, Tenmalai, Wynaad and from Mysore. Characters distinguishing Noemacheilus 


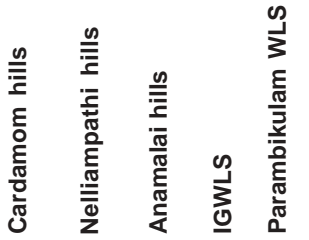

Order: Osteoglossiformes

Suborder: Notopteroidei

Family: Notopteridae

Notopterus notopterus (Pallas)*

Order: Anguiliformes

Family: Anguillidae

Anguilla bengalensis (Gray)

Subfamily: Danioninae

Tribe: Oxygasterini

Barilius bakeri Day\#

Barilius bama (Hamilton)

Barilius bendelesis (Hamilton)

Barilius gatensis (Val.)\#

Salmostoma acinaces (Val.)

Salmostoma boopis (Day)\#

Salmostoma clupeoides (Bloch)

Tribe: Danionini

Amblypharyngodon microlepis (Bleeker)*

Chela laubuca (Hamilton)

Esomus danricus (Hamilton)

Esomus thermoicos (Val.)*

Danio aequipinnatus (Mc Clelland)

Danio malabaricus (Jerdon)*

Rasbora caverii (Jerdon)*

Rasbora daniconius (Hamilton)

Subfamily: Cyprininae

Tribe: Cyprinini

Subtribe: Cyprini

Cyprinus carpio communis (Linn.)*

Subtribe: Tores

Tor khudree (Sykes)

Tribe: Systomini

Subtribe: Osteobramae

Osteobrama bakeri Day\#

Subtribe: Systomi

Barbodes carnaticus (Jerdon)

Barbodes sarana subnasutus (Val.)

Hypselobarbus curmuca (Hamilton)\#

Hypselobarbus denisoni (Day)\#

Hypselobarbus dobsoni (Day)\#

Hypselobarbus dubius (Day)*\#

Hypselobarbus thomassi (Day)\#

Puntius amphibius (Val.)

Puntius bimaculatus (Bleeker) ${ }^{*}$

Puntius chola (Hamilton)

Puntius dorsalis (Jerdon)

Puntius filamentosus (Val.)

Puntius melanampyx Day

Puntius melanostigma (Day)

Puntius punctatus (Day)*

Puntius sophore (Hamilton) ${ }^{\star}$

Puntius ticto (Hamilton)

Tribe: Semiplotini

Osteochilichthys thomassi (Day)\#

Osteochilichthys longidorsalis Pethiyagoda \& Kottelat

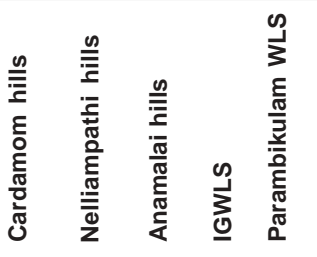

Tribe: Labeonin

Catla catla (Hamilton) ${ }^{*}$

Cirrhinus mrigala (Hamilton)*

Labeo rohita (Hamilton)*

Subfamily: Garrinae

Garra hughi (Silas) ${ }^{*} \#$

Garra mcclellandi (Jerdon)*\#

Garra mullya (Sykes)

Garra surendranathanii Shaji, Easa \& Arun \#

Family: Balitoridae

Subfamily: Balitorinae

Bhavania australis (Jerdon)*\#

Homaloptera montana Herre \#

Travancoria jonesi Hora \#

Subfamily: Noemacheilinae

Mesonemacheilus herrei Nalbant \& Banarescu) \#

Mesonemacheilus guentheri Day \#

Mesonemacheilus triangularis (Day) \#

Nemacheilus monilis Hora*\#

Schistura denisoni denisoni (Day) ${ }^{\star}$

Family: Cobitidae

Subfamily: Cobitinae

Lepidocephalus thermalis (Val.)

Order: Siluriformes

Family: Bagridae

Batasio travancoria Hora \& Law \#

Mystus armatus (Day)

Mystus cavasius (Hamilton)

Mystus gulio (Hamilton)

Mystus malabaricus (Jerdon)*\#

Mystus montanus (Jerdon)

Mystus vittatus (Bloch)

Family: Siluridae

Ompok bimaculatus (Bloch)*

Ompok malabaricus (Val.)\#

Family: Sisoridae

Glyptothorax anamalaiensis Silas \#

Glyptothorax housei Herre \#

Glyptothorax lonah (Sykes)

Family: Clariidae

Clarias batrachus (Linn.)

Family: Heteropneustidae

Heteropneustes fossilis (Bloch)

Heteropneustes longipectoralis Remadevi

\& Raghunathan *\#

Order: Mugiliformes

Family: Mugilidae

Rhinomugil corsula (Hamilton) ${ }^{*}$

Order: Beloniformes

Family: Belonidae

Xenentodon cancila (Hamilton)

Order: Cyprinodontiformes

Family: Aplocheilidae

Aplocheilus lineatus (Val.)

.




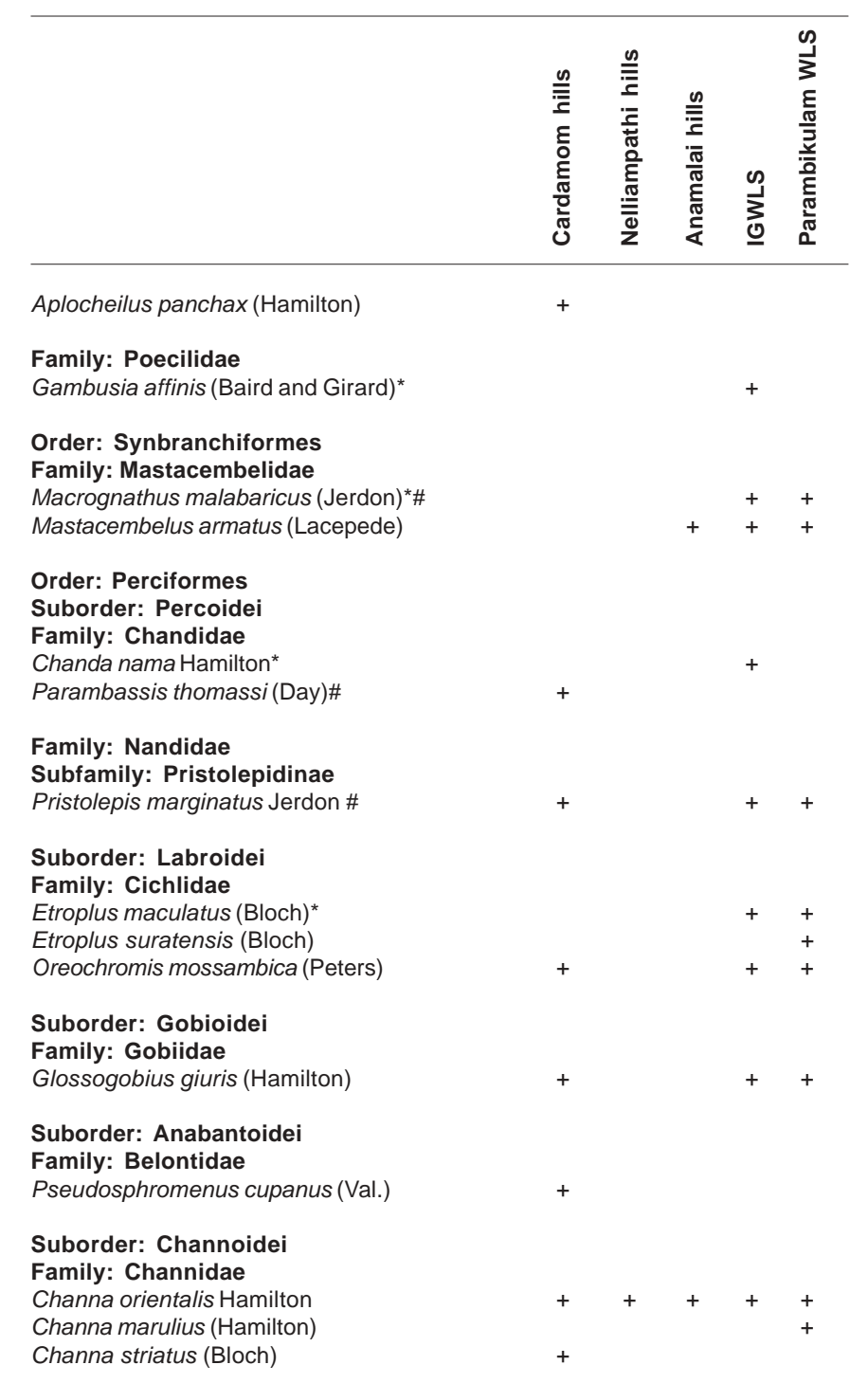

* - New Additions to IGWLS, Anamalai Hills; \# - Endemic to Western Ghats; Cardamom hills (Jayaram, 1976); Nelliampathi hills (Silas, 1951); Anamalai hills (Silas, 1951); IGWLS, Anamalai hills (Recent Collections);

Parambikulam WLS (Biju et al., 1999)

herrei, endemic to Anamalai hills from its closely related species Noemacheilus guentheri has been recently discussed (Rema Devi \& Indra, 2002).

Of ichthyological significance is the presence of 29 species endemic to Western Ghats occurring in these ranges (Table 1). Of these endemics found in Anamalais, the following species are restricted only to these hill ranges, viz., Garra hughi, G. surendranathanii, Noemacheilus herrei, Glyptothorax anamalaiensis and Glyptothorax housei. Garra hughi earlier described from Travancore has also been reported from Palani hills, which is the eastern extension of the Anamalai hill ranges.

\section{REFERENCES}

Biju, C.R., K. Raju Thomas and C.R. Ajith Kumar (1999). Fishes of Parmabikulam Wild Life Sanctuary, Palakkad district, Kerala. Journal of the Bombay Natural History Society 96(1): 82-87.

Day, F. (1865). The fishes of Malabar. London, Quaritch, 293pp.

Day, F. (1875-78). The Fishes of India, being a natural history of the fishes known to inhabit the seas and freshwaters of India, Burma and Ceylon. Text and Atlas in 4 parts, London, 778pp+195pls.

Indra, T.J., K. Rema Devi and M.B. Raghunathan (1998). A new record of a rare loach, Noemacheilus monilis from Anamalai hills, Western Ghats, Tamil Nadu. Journal of the Bombay Natural History Society 95(3): 521-522.

Herre, A.W.C.T. (1942). Glyptothorax housei, a new sisorid catfish from south India. Stanford Ichthyological Bulletin 2(4): 117-118.

Herre, A.W.C.T. (1945). Notes on fishes in the Zoological Museum of Stanford University. New fishes from China and India. A new genus and a new Indian record. Journal of Washington Academy of Science 35: 399-404.

Jayaram, K.C. (1999). The Freshwater Fishes of the Indian Region. Narendra Publishing House, New Delhi, xxvii+551+xviiipls.

Jayaram, K.C., T.J. Indra and M. Sunder Singh (1976). On a collection of fish from the Cardamom hills, South India. Madras Journal of Fisheries 7: 1-7.

Menon, A.G.K. (1999). Checklist- Freshwater Fishes ofIndia. Records of Zoological Survey of India, Occassional Paper No. 175: I-XXVIII, 1-366pp.

Pethiyagoda, R. and M. Kottelat (1994). Three new species of fishes of the genera Gsteochilichthys (Cyprinidae), Travancoria (Balitoridae) and Harobagrus (Bagridae) from Chalakudy river, Kerala, India. Journal of South Asian Natural History 1: 97-116.

Rema Devi, K. and T.J. Indra (1999). Some observations on Garra hughi Silas from Anamalai hills, Western Ghats, Tamil Nadu, India. Records of the Zoological Survey of India 97(4): 53-59.

Rema Devi, K. and T.J. Indra (2002). A note on Mesonoemacheilus herrei Nalbant and Banarescu (Cypriniformes: Balitoridae: Noemacheilinae). Journal of the Bombay Natural History Society 99(2): 333-337.

Rema Devi, K. and M.B. Raghunathan (1999). Heteropneustes longipectoralis (Siluriformes: Heteropneustidae) a new species from the Anamalai Hills, in the western Ghats. Records of the Zoological Survey of India 97(3): 109-115.

Shaji, C.P., P.S. Easa and L.K. Arun (1996). Garra surendranathanii - A new cyprinid fish from the southern Western Ghats, India. Journal of the Bombay Natural History Society 93: 572-575.

Silas, E.G. (1951). On a collection of fish from the Anamali and Nelliampathi hills ranges (Western Ghats) with notes on its zoogeographical significance. Journal of the Bombay Natural History Society 49(4): 670-681.

\section{ACKNOWLedGements}

The authors are thankful to the Director, Zoological Survey of India and the Officer-in-Charge, Southern Regional Station for the facilities provided. Our special thanks are due to Dr. R. Suresh Kumar, Research Scholar, Southern Regional Station, for the assistance rendered. 